\title{
Phagocytosis and killing of Gardnerella vaginalis by human neutrophils
}

\author{
CSF EASMON, L CLARK, JP CRANE, R GREEN \\ From the Department of Medical Microbiology, Wright-Fleming Institute, St Mary's Hospital Medical School, \\ London W2
}

SUMMARY Gardnerella vaginalis was ingested and killed by neutrophils in the presence of normal human serum. Heat inactivation of the serum inhibited these processes. The opsonisation of some but not all $G$ vaginalis strains was enhanced by immune rabbit serum. Immune serum did not, however, enhance intracellular killing. Blockade of the classical pathway of complement activation had no effect on the opsonic activity of human serum. These results suggest that the opsonisation, phagocytosis, and killing of $G$ vaginalis by human serum and neutrophils is primarily mediated by complement activated by the alternative pathway. Serum without neutrophils has little effect on the viability of $G$ vaginalis.

Gardnerella vaginalis is closely associated with bacterial vaginosis, ${ }^{1}$ which is a superficial infection of the vaginal mucosa. Occasionally, $G$ vaginalis causes invasive disease such as endometritis, amnionitis, and bacteraemia. ${ }^{2}{ }^{3}$ Recently, it has been implicated as a possible cause of preterm labour and other complications of pregnancy. ${ }^{4}$ Although some work has been done on the adherence of $G$ vaginalis to cells, ${ }^{5-7}$ other aspects of its interaction with host defences have not been investigated.

We report here some preliminary studies on the opsonisation and phagocytosis of $G$ vaginalis and its killing by human neutrophils, as phagocytosis is likely to be the main defence against invasive gardnerella infections.

\section{Material and methods}

\section{BACTERIA}

$G$ vaginalis NCTC 10915 and four clinical isolates, strains $33,35,36$, and 39 , were used. Isolates were identified as previously described. ${ }^{8} G$ vaginalis was grown in $7 \% \mathrm{CO}_{2}$ either in peptone starch dextrose broth supplemented with $10 \%$ (vol/vol) horse serum or on bilayer Columbia agar plates, the upper layer being supplemented with $5 \%$ (vol/vol) time expired human blood.

\section{OPSONISATION}

For chemiluminescence and phagocytosis experi-

Accepted for publication 28 February 1985 ments a washed $48 \mathrm{~h}$ culture of $G$ vaginalis was incubated for $30 \mathrm{~min}$ at $37^{\circ} \mathrm{C}$ in Hank's balanced salt

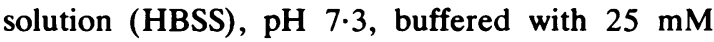
HEPES, to which had been added one of the following: $10 \%$ pooled human serum; $10 \%$ normal human serum heated for $30 \mathrm{~min}$ at $56^{\circ} \mathrm{C} ; 10 \%$ human serum chelated with magnesium sulphate and ethylene glycol tetraacetate; or 5\% normal human serum plus $5 \%$ immune rabbit serum raised against $G$ vaginalis.

Bacteria were then washed and resuspended to the required concentration in HBSS.

\section{PHAGOCYTOSIS}

This was measured either by a simple microscopical assay or by luminol dependent chemiluminescence. Human neutrophils were separated from venous blood by dextran sedimentation and residual red cells were lysed by treatment wth $0.83 \%$ Tris buffered ammonium chloride. ${ }^{9}$ After a wash, neutrophils were counted and resuspended to a concentration of $10^{6} \mathrm{cells} / \mathrm{ml}$ in HBSS without phenol red.

For microscopical assays bacteria and cells were incubated at a ratio of $5: 1$ for $15 \mathrm{~min}$ at $37^{\circ} \mathrm{C}$. Smears were then prepared using a cytospin centrifuge (Shandon) and stained with Giemsa. The number of neutrophils with ingested bacteria was then counted.

For luminol dependent chemiluminescence a bacterial cell ratio of about 100:1 was used. Luminol was dissolved in dimethyl-sulfoxide and diluted to a final concentration of $2 \times 10^{-5} \mathrm{~mol} / \mathrm{l}$. Luminescence 
Table 1 Opsonisation of Gardnerella vaginalis strains measured by microscopical assay and by luminol dependent chemiluminescence (CL)

\begin{tabular}{|c|c|c|c|c|c|c|c|c|}
\hline \multirow[t]{3}{*}{ Opsonin source } & \multicolumn{8}{|c|}{ Opsonisation of $G$ vaginalis strain } \\
\hline & \multicolumn{2}{|l|}{ Strain 10915} & \multicolumn{2}{|l|}{ Strain 33} & \multicolumn{2}{|l|}{ Strain 35} & \multicolumn{2}{|l|}{ Strain 36} \\
\hline & \% Phagocytosis & $C L(m V)$ & $\%$ Phagocytosis & $C L(m V)$ & $\%$ Phagocytosis & $C L(m V)$ & \% Phagocytosis & $C L(m V)$ \\
\hline $\begin{array}{l}\text { Unopsonised } \\
10 \% \text { normal human serum } \\
10 \% \text { normal human serum } \\
\text { heated at } 56^{\circ} \mathrm{C} \text { for }\end{array}$ & $\begin{array}{l}31 \\
72 \\
1\end{array}$ & $\begin{array}{r}51 \\
222\end{array}$ & $\begin{array}{l}36 \\
76\end{array}$ & $\begin{array}{l}36 \\
74\end{array}$ & $\begin{array}{l}28 \\
59\end{array}$ & $\begin{array}{l}10 \\
44\end{array}$ & $\begin{array}{l}42 \\
90\end{array}$ & $\begin{array}{r}24 \\
225\end{array}$ \\
\hline $\begin{array}{l}30 \text { min } \\
10 \% \text { human serum } \\
\text { chelated with magnesium } \\
\text { sulphate and ethylene }\end{array}$ & 33 & 60 & 35 & 32 & 29 & 19 & 40 & 59 \\
\hline $\begin{array}{l}\text { glycol tetraacetate } \\
5 \% \text { normal human serum } \\
\text { plus } 5 \% \text { immune rabbit } \\
\text { serum }\end{array}$ & 69 & 306 & 74 & 85 & 82 & 33 & 88 & 208 \\
\hline
\end{tabular}

Table 2 Opsonisation of four strains of Gardnerella vaginalis by normal human serum and three hyperimmune rabbit antisera

\begin{tabular}{|c|c|c|c|c|c|c|c|c|}
\hline \multirow[t]{3}{*}{ Opsonin source } & \multicolumn{8}{|c|}{ Opsonisation of $G$ vaginalis strains } \\
\hline & \multicolumn{2}{|l|}{ Strain 10915} & \multicolumn{2}{|l|}{ Strain 35} & \multicolumn{2}{|l|}{ Strain 36} & \multicolumn{2}{|l|}{ Strain 39} \\
\hline & \% Phagocytosis & $C L(m V)$ & \% Phagocytosis & $C L(m V)$ & \% Phagocytosis & $C L(m V)$ & $\%$ Phagocytosis & $C L(m V)$ \\
\hline $\begin{array}{l}\text { Normal human serum } \\
\text { Normal human serum plus } \\
\text { immune rabbit }\end{array}$ & $s^{71}$ & 141 & 85 & 41 & 100 & 128 & 86 & 103 \\
\hline $\begin{array}{l}\text { serum- } 167 \\
\text { Normal human serum plus } \\
\text { immune rabbit }\end{array}$ & 91 & 176 & 92 & 65 & 100 & 131 & 97 & 111 \\
\hline $\begin{array}{l}\text { serum- } 166 \\
\text { Normal human serum plus } \\
\text { immune rabbit }\end{array}$ & s & 130 & 89 & 58 & 100 & 175 & 90 & 97 \\
\hline serum-167 & 65 & 124 & 82 & 28 & 100 & 133 & 82 & 76 \\
\hline
\end{tabular}

Table 3 Killing of Gardnerella vaginalis strains 10915 and 39 by normal human serum, immune rabbit serum, and human neutrophils

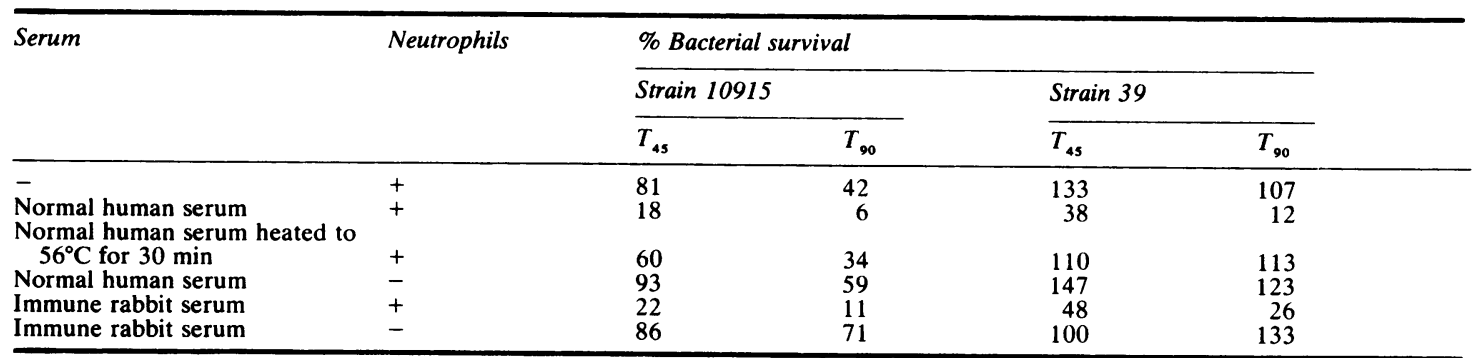

$T_{45}=45 \mathrm{~min}$ incubation; $T_{90}=90 \mathrm{~min}$ incubation.

was measured at a fixed time of 15 min after initial mixing of cells and bacteria. A luminometer 1250 (LKB) was used and the reaction was measured at $37^{\circ} \mathrm{C} .^{9}$

PHAGOCYTIC KILLING

Neutrophils were mixed with $G$ vaginalis at a bacterial cell ratio of roughly $5: 1$. The medium was HBSS supplemented with either $10 \%$ normal human serum, $10 \%$ normal human serum heated at $56^{\circ} \mathrm{C}$ for $30 \mathrm{~min}$, or $5 \%$ normal human serum plus $5 \%$ immune rabbit serum raised against $G$ vaginalis. Serum and cell free controls were included. Bacterial counts were made at the start of the experiment and after 45 and 90 min by taking $0.1 \mathrm{ml}$ aliquots of reaction mixture into $0.9 \mathrm{ml}$ of distilled water and sonicating to disrupt the cells. Surface viable counts were then made on 10-fold dilutions of this sonicate. IMMUNE RABBIT SERUM

Three immune rabbit sera (IRS) were prepared by intravenous injection of $G$ vaginalis into New Zealand white rabbits using the method of Vice and Smaron. ${ }^{10}$ IRS- 163 was raised against $G$ vaginalis NCTC 10915. The other sera IRS-166 and IRS-167 were raised against clinical isolates of $G$ vaginalis unrelated to those used in the phagocytosis experiments. 


\section{Results}

Table 1 shows the phagocytosis of the NCTC strain of $G$ vaginalis and the three clinical isolates measured by microscopical assay and chemiluminescence. Both techniques gave similar patterns of results. All four strains were opsonised by normal human serum and the opsonic activity was removed by heat inactivation. Blockade of the classical pathway of complement activation by chelating normal human serum with magnesium sulphate and ethylene glycol tetraacetate had no effect on the opsonisation of $G$ vaginalis. The use of IRS-163 raised against $G$ vaginalis 10915 produced a moderate enhancement of opsonisation of both this strain and strain 35 but not of strains 33 and 36 .

We investigated this apparent heterogeneity of opsonic requirements among $G$ vaginalis strains by comparing the opsonic effect of three immune rabbit sera against $G$ vaginalis $10915,35,36$, and 39 . IRS-163 again produced a moderate enhancement of opsonisation of strain 10915 in comparison with normal human serum, but neither IRS-166 nor IRS-167 had any such effect. IRS-166 enhanced opsonisation of strains 35 and 36 but not of strain 39 . IRS did not enhance the opsonisation of any of the four test strains (Table 2).

Assays of phagocytic killing were carried out with strains 10915 and 39. Both strains were resistant to killing by both normal human serum and immune rabbit serum in the absence of neutrophils. Unopsonised organisms were killed poorly by neutrophils. Killing was at its maximum in the presence of normal human serum and neutrophils. The use of IRS163 in this system did not result in greater killing of $G$ vaginalis than that seen with normal human serum. Finally, heat inactivation of serum prevented effective neutrophil killing (Table 3). The clinical strain 39 was more resistant to killing than the NCTC strain.

\section{Discussion}

$G$ vaginalis is opsonised and killed by fresh human serum and neutrophils. These processes are complement dependent. None of the strains tested was susceptible to serum killing in the absence of neutrophils. Although complement dependent, opsonisation and phagocytosis were unaffected by blockade of the classical pathway. $G$ vaginalis contains lipopolysaccharide, which is a potent activator of the alternative complement pathway. ${ }^{11}$

The role of antibody is less clear. The hyperimmune rabbit antisera originally raised for immunofluorescence tests produced only moderate enhancement of opsonisation limited to certain strains and had no effect on intracellular killing. The strain differences in response to antibody mediated opsonisation mirror differences in the immunofluorescence and enzyme linked immunosorbent assay reactions of $G$ vaginalis strains that we have observed. This work needs to be extended as it may form the basis of a possible serotyping system.

The effectiveness of cells and serum in killing $G$ vaginalis is what one would expect of an organism of low virulence. Yet in some circumstances $G$ vaginalis can cause invasive disease, even bacteraemia. We need to see whether strains from such infections are more capable of resisting host defences.

Women and babies with such infections need to be studied to see if they have defects in their humoral or cellular immune responses to $G$ vaginalis. We also need to see whether clinical infection results in the production of opsonic or bactericidal antibody and to investigate the surface structures of the organism and their capacity to activate the complement system.

We thank the Medical Research Council for financal support.

\section{References}

' Gardner HL, Dukes CD. A newly defined specific infection previously classified "non-specific vaginitis" Am J Obstet Gynecol 1955;69:962-76.

${ }^{2}$ Monif GRG, Baer H. Haemophilus (Corynebacterium) vaginalis septicemia. Am J Obstet Gynecol 1974;120:1041-5.

${ }^{3}$ Gardner HL. Haemophilus vaginalis vaginitis after twenty-five years. Am J Obstet Gynecol 1980;137:385-90.

${ }^{4}$ Eschenbach DS, Gravett MG, Chen KCS, Hoyme UB, Holmes $\mathrm{KK}$. Bacterial vaginosis during pregnancy. An association with prematurity and post-partum complications. In: Mårdh P-A, Taylor-Robinson D, eds. Bacterial Vaginosis. Stockholm: Almqvist and Wiksell International, 1984:213-22.

${ }^{5}$ Mårdh P-A, Westrom L. Adherence of bacteria to vaginal epithelium. Infect Immun 1976;13:661-6.

- Sobel JD, Schneider J, Kaye D, Levison ME. Adherence of bacteria to vaginal epithelial cells at various times of menstrual cycle. Infect Immun 1981;32:194-7.

' Ison CA, Easmon CSF. Studies on the mechanism of adhesion of Gardnerella vaginalis to human erythrocytes. In: Mårdh P-A, Taylor-Robinson D, eds. Bacterial Vaginosis. Stockholm: Almqvist and Wiksell International, 1984:191-3.

${ }^{8}$ Ison CA, Easmon CSF. Carriage of Gardnerella vaginalis and anaerobes in semen. Genito Urinary Medicine (in press).

' Easmon CSF, Cole PJ, Williams AJ, Hastings MJG. The measurement of opsonic and phagocytic function by luminoldependent chemiluminescence. Immunology 1980;41:67-74.

${ }^{10}$ Vice JL, Smaron MF. Indirect fluorescent-antibody method for the identification of Corynebacterium vaginale. Appl Microbiol 1973;25:908-16.

"Greenwood JR, Pickett MJ. Transfer of Haemophilus vaginalis Gardner and Dukes to new genus Gardnerella $G$ vaginalis (Gardner and Dukes) comb nov. Int J System Bacteriol 1980; 30: 170-8.

Requests for reprints to: Professor CSF Easmon, Department of Medical Microbiology, Wright-Fleming Institute, St Mary's Hospital Medical School, London W2 1PG, England. 